\title{
Article
}

\section{Mobile phones in the diffusion of knowledge and persistence in inclusive human development in Sub-Saharan Africa}

\author{
Asongu, Simplice and Nwachukwu, Jacinta Chikaodi
}

Available at http://clok.uclan.ac.uk/24920/

Asongu, Simplice and Nwachukwu, Jacinta Chikaodi ORCID: 0000-0003-29879242 (2017) Mobile phones in the diffusion of knowledge and persistence in inclusive human development in Sub-Saharan Africa. Information

Development, 33 (3). pp. 289-302. ISSN 0266-6669

It is advisable to refer to the publisher's version if you intend to cite from the work. http://dx.doi.org/10.1177/0266666916655189

For more information about UCLan's research in this area go to http://www.uclan.ac.uk/researchgroups/ and search for <name of research Group>.

For information about Research generally at UCLan please go to http://www.uclan.ac.uk/research/

All outputs in CLoK are protected by Intellectual Property Rights law, including Copyright law. Copyright, IPR and Moral Rights for the works on this site are retained by the individual authors and/or other copyright owners. Terms and conditions for use of this material are defined in the policies page. 


\section{$\underline{\text { A G D I Working Paper }}$}

\section{WP/16/009}

Mobile Phones in the Diffusion of Knowledge and Persistence in Inclusive Human Development in Sub-Saharan Africa

Forthcoming: Information Development

\section{Simplice Asongu}

African Governance and Development Institute,

P. O. Box 8413, Yaoundé, Cameroon.

E-mail: asongusimplice@yahoo.com

\section{Jacinta C. Nwachukwu}

Department of Economics, Finance and Accounting,

Faculty of Business, Environment and Society,

Coventry University

Priory Street, Coventry, CV1 5DH, UK

Email: jacinta.nwachukwu@ coventry.ac.uk 


\title{
AGDI Working Paper
}

Research Department

\section{Mobile Phones in the Diffusion of Knowledge and Persistence in Inclusive Human Development in Sub-Saharan Africa}

\section{Simplice A. Asongu \& Jacinta C. Nwachukwu}

March 2016

\begin{abstract}
The success of inclusive development strategies in the post-2015 sustainable development agenda depends substantially on the adoption of common inclusive development policies among nations. Building on the relevance of a knowledge economy in the post-2015 development agenda, this study models the feasibility of common policies for inclusive human development in Sub-Saharan Africa (SSA). More specifically, we investigate the complementary role of knowledge diffusion in the inclusive benefits of mobile phone penetration in SSA from 2000 to 2012 by employing the Generalised Method of Moments. Knowledge diffusion variables include educational quality, innovation and internet penetration. The main finding is that inclusive human development is persistently conditional on mobile phones in knowledge diffusion. Moreover, countries with low levels of inclusive human development are catching-up their counterparts with higher development. Policy implications are discussed with particular emphasis on how to leverage common knowledge economy initiatives for inclusive development.
\end{abstract}

JEL Classification: G20; I10; I32; O40; O55

Keywords: Mobile phones; catch-up; inclusive human development; Africa 


\section{Introduction}

Assessing mobile phones $^{1}$ in the diffusion of knowledge for inclusive human development in Sub-Saharan Africa (SSA) has at least a fivefold motivation. They are that the region is characterised by: (i) a lagging position in the knowledge economy (KE); (ii) increasing extreme poverty levels; (iii) healthy prospects for mobile penetration in the near future; (iv) evidence of recently documented benefits of mobile phones in inclusive development and (v) the need for common inclusive development policies in the post-2015 development agenda.

First, globalisation has become an ineluctable phenomenon whose challenges cannot be neglected without sacrificing the prosperity of nations. In essence, it is increasingly apparent that for nations to be integrated into the world economy, they are required to be competitive. Competition in the $21^{\text {st }}$ century has been substantially documented to be centred on the knowledge economy (KE) (Tchamyou, 2015; Asongu, 2015a; Oluwatobi et al., 2015). According to the narrative: (i) Europe and North America have mastered the dynamics of KE and inexorably driving development in the international arena; (ii) the historic pattern formulated by Japan has set the course for the Newly Industrialized Economies of Asia (Hong Kong, Singapore, South Korea and Taiwan, China and Malaysia) and (iii) Latin America and other Asian countries have been responding to globalisation in calculated steps that underscore the imperative for knowledge-based economies in their ongoing pursuits of regional initiatives. Unfortunately, in sharp contrast to the above trends, Africa's knowledge index has been falling since the beginning of the $21^{\text {st }}$ century (Anyanwu, 2012; Asongu, 2015b).

Second, an April 2015 report from the World Bank on the achievement of Millennium Development Goals (MDGs) has shown that extreme poverty has been decreasing in all regions of the world with the exception of SSA (World Bank, 2015). Accordingly, 45 percent of countries in the sub-region were off-track from reaching the MDG target of halving extreme poverty by the end 2015 . This outcome is surprising because the sub-region has been enjoying over decades of growth resurgence that began in the mid-1990s (Fosu, 2015a, p. 44). This contradiction has motivated a recent stream of literature devoted to assessing and explaining the sub-region's economic tragedy, notably a book by: (i) Fosu (2015bc) devoted to examining whether Africa's growth revival is a reality or a myth and (ii) Kuada (2015)

\footnotetext{
1 The terms, 'mobile phone penetration', 'mobile', 'mobile phones' and 'mobile telephony' are used interchangeably throughout the paper.
} 
which introduces a new paradigm on 'soft economics' (or human capability development) as an alternative means to understanding developing trends in Africa.

Third, prospects of mobile phone penetration in Africa are promising and encouraging. In essence, while high-end markets in Asia, Europe and North America are characterised with stabilization in the growth of mobile phones, developing African markets still project substantial business opportunities centred on mobile penetration (Asongu, 2015c). Furthermore, consistent with Penard et al. (2012), whereas mobile phone and internet penetrations in developed countries have reached saturation points, their development on the African continent have been asymmetric with respectively 41 and 9.6 percent penetration rates.

Fourth, there is a growing stream of development literature that has documented a plethora of inclusive benefits from mobile phones. Accordingly, mobile phones have been known to: (i) enhance opportunities for doing business (Ondiege, 2010, p. 11; Mishra \& Bisht, 2013, p. 505); (ii) improve household management efficiency (Al Surikhi, 2012; Asongu, 2014a); (iii) eliminate waste in the agricultural sector via reductions of demandsupply mismatches as well as demand- and supply-side constraints (Muto \& Yamano, 2009; Aker \& Fafchamps, 2010); (iv) promote inclusive finance (Singh, 2012, p. 466; Kirui et al. 2013, p. 141); (v) bridge the gap between rural and urban areas (Qiang et al., 2011, pp. 14-26; Chan \& Jia, 2011, pp. 3-5); (vi) empower women (Maurer, 2008; Ojo et al., 2012); (vii) promote the informal economic sector to the detriment of its formal component (Asongu, 2013a) and (viii) reduce income-inequality (Asongu, 2015d).

Fifth, the rationale for common inclusive development policies in SSA has a twofold motivation. On the one hand, post-2015 Sustainable Development Goals (SDGs) are common among countries. On the other hand, consistent with the discourse above, there are common issues in knowledge and poverty/inequality across countries in the sub-region.

In the light of the above, this inquiry contributes to the literature by assessing the case of mobile phones in the diffusion of knowledge for inclusive human development in SSA. While the policy relevance of the inquiry builds on the first-three strands above, we engage the fourth and fifth strands in substantive detail in Section 2 in order to clearly articulate how the inquiry steers clear of the highlighted literature on the positive role of mobile phones in inclusive development. Irrespective of engaged strands, scholars who have been cautious in not considering the mobile phone as a silver bullet for economic development have also 
consistently been requesting more scholarly research on the development outcomes of mobile phones (Mpogole et al., 2008, p. 71; Asongu \& De Moor, 2015).

The rest of this study is structured as follows. Section 2 presents the theoretical underpinnings and reviews the literature on the relationship between mobile phone penetration and inclusive development. The data and methodology are discussed in Section 3. Section 4 presents the empirical results, discussion and implications while Section 5 concludes.

\section{Related literature and theoretical underpinnings}

\subsection{Mobile phone penetration and inclusive development}

A plethora of inclusive development benefits have been documented as being associated with the progress of mobile telephony in developing countries. Consistent with Asongu and De Moor (2015), the underlying benefits have intersected with almost all fabrics of African society through enhanced corporate and household management. According to the authors, such improvements have been articulated by consistent adjustments of interactive networks, which have led to, inter alia: (i) better channels of monitoring health-care; (ii) consolidation of household-to-business, business-to-business and household-to-household networks; (iii) improvements in payment facilities for Small and Medium Sized Enterprises (SMEs) and (iv) closing of the rural-urban divide. We discuss highlighted inclusive benefits in three strands: (i) reduction of the gender divide; (ii) improvement of health services and (iii) mitigation of the rural/urban gap.

In the first strand, there is a substantial body of literature on the instrumentality of mobiles in gender inclusiveness, especially on the empowerment of women through financial inclusion channels. The recognized channels have centered on better coordination in household management and female-managed SMEs (Asongu, 2014a). Other benefits include: multi-tasking, education and cost reduction (Jonathan \& Camilo, 2008; Ondiege, 2010, 2013; Al Surikhi, 2012; Asongu, 2015d). In accordance with Asongu and De Moor (2015), the underlying gender inclusive benefits would be enhanced through better government intervention. This position in consistent with (i) Maurer (2008) who had earlier articulated the need for more policy coordination and (ii) Ojo et al. (2012) on the instrumentality of mobile phones in improving the livelihoods of females in Ghana. The interested reader may consult Ondiege (2010, p.11) and Bisht (2013, p. 505) for strategies and approaches that are countryspecific. 
The second element on health services is characterized by the evolving evidence that the mobile telephony is being constantly used to improved health-service delivery. According to West (2013), facilities from the device are important in the provision of affordable medical services. It follows that geography and income barriers which have been inhibiting 'health care delivery' are increasingly being lifted with specifically-tailored mobile services. Some of the documented channels via which such results are achievable include: access to reference material, assessment of medical records and efficiency in laboratory tests. In accordance with the relevant literature, these medical services have been adapted to, among other; better tailored feedback because of enhanced self-monitoring (Bauer et al., 2010), improved observation and treatment of patients with tuberculosis (Hoffman et al., 2010) and more efficient management of clinical appointments (De Costa et al., 2010). In accordance with Kliner et al. (2013), rural communities are those which most benefit from the development externalities of health-tailored mobile phone applications. Kirui et al. (2013) confirmed the position of Kliner et al. on the relative weight of mobiles in the negative poverty-externalities on rural communities: 'We conclude that mobile phone-based money transfer services in rural areas help to resolve a market failure that farmers face; access to financial services' (p. 141). This position is also in accordance with Ssozi and Amlani (2015) on the relevance of targeted health-spending in reducing the rural-urban divide.

In the third stream, we find studies that are supportive of the role of mobile phones in reducing the rural-urban divide. Some of the documented mechanisms by which the underlying gap is reduced include: (i) addressing concerns in unemployment on the one hand and the production and distribution of food on the other; (ii) supporting cooperatives and SMEs and (iii) mitigating demand- and supply-side barriers for productivity in agriculture. To begin with, challenges to employment as well as the production and distribution of food are increasingly been tackled with the help of mobile phones. (1) E-agriculture, (2012, p. 6-9) provides an example in Ghana where information sharing improved the revenue of traders by 10 percent. (2) We have already substantially shown how mobiles are improving the livelihoods of the rural population by lifting barriers on agricultural productivity and mitigating supply- and demand-side constraints (Muto \& Yamano, 2009; Aker \& Fafchamps, 2010). Asongu and De Moor (2015a) observed that the return on agricultural productivity for farmers can be improved by reducing highlighted constraints through better 'matching practices' and networking channels. It follows that in rural areas, mobile banking services are complementing agricultural finance in support of cooperatives and SMEs. A case in point is 
the Community Credit Enterprises (CCE) in Costa Rica through the development of business sustainability models and support to groups that are financially sustainable (Perez et al., 2011, p. 316).

The narratives of the third strand are consistent with the World Bank views on the relevance of mobile telephony in rural and agricultural progress (Qiang et al., 2011, pp. 1426). This perspective is supported by Chan and Jia (2011) on the rewards of mobile phones in access to finance 'mobile banking is an ideal choice for meeting the rural financial needs' ( $\mathrm{p}$. 3), partially due to growing 'rates for bank transfers through mobile cell phones at commercial banks' (p. 5). Warren (2007) has postulated that the positive externalities from mobile phones are more apparent in rural communities. This is probably because they substantially reduce information asymmetry by mitigating constraints on information acquisition and the purchase of commodities. In India for example, Singh (2012, p. 466) has shown that mobile phones are increasing financial inclusion in rural areas. This may probably be because 'Telecommunication infrastructure growth especially mobile phone penetration has created an opportunity for providing financial inclusion' (Mishra \& Bisht, 2013, p. 503).

\subsection{Intuition and theoretical underpinnings}

The intuition motivating the inquiry is in accordance with the income catch-up literature that has been substantially documented within the framework of neoclassical growth models (Barro, 1991; Barro \& Sala-i-Martin, 1992, 1995; Mankiw et al., 1992; Baumol, 1986) and recently extended to other fields of economic development, notably, in: (i) negative signals like bad governance, unemployment and inflation (Asongu \& Nwachukwu, 2016) and (ii) positive signals like financial market performance (Narayan et al., 2012; Bruno et al., 2012) and inclusive human development (Mayer-Foulkes, 2010; Asongu, 2014b). Both motions build on the assumption of diminishing cross-country dispersions in investigated factors as a basis for the adoption of common policies.

In the post-Kenynesian era, initial economic growth theories that gained prominence with the resurfacing of the neoclassical revolution have facilitated cross-country convergence. Within this framework, extension of concepts in market equilibrium provided the foundations of economic growth theories that forecasted absolute convergence. In this context, cross country-convergence is the result of policies that are favourable to 'free-market competition' (Mayer-Foulkes, 2010). Seminal (Barro, 1991) and later (Pritchett, 1997) established the absence of catch-up (or absolute divergence) in per capita income. One strand of the literature 
which builds on the endogenous theory of growth contends that there are two main reasons for the absence cross-country income convergence: disparities in initial endowments and the likelihood of multiple equilibria. Another strand based on exogenous growth theory argues that, irrespective of disparities in initial income levels, catch-up in income levels is still likely in each country's long run equilibrium.

Putting the above theoretical underpinnings into perspective, it is reasonable to expect that the elimination of cross-country differences in inclusive human development would lead to common policy initiatives for two main reasons. First, evidence of catch-up in inclusive development denotes that countries with lower levels of inclusive development are catchingup with their counterparts with higher levels of inclusive human development. Second, with complete or full catch-up in inclusive human development, cross-country variations in inclusive development are no longer apparent, such that common policies can be adopted and implemented without distinction of nationality (Asongu, 2013b).

\section{Data and methodology}

\subsection{Data}

The study examines a panel of forty-nine countries in SSA with data from the African Development Indicators of the World Bank for the period 2000-2012. Consistent with recent African inclusive development literature (Asongu et al., 2015, 2016), inclusive development is measured with the inequality-adjusted human development index (IHDI). The IHDI is the national average of achievements in three main areas, namely: (i) knowledge; (ii) health and long life and (iii) decent standards of living. In addition to accounting for average rewards in terms of health, education and health, the IHDI also accounts for the distribution of underlying achievements among the population by controlling for mean values of each dimension with regards to inequality.

The main independent variable of interest is the lagged dependent variable. If the estimated lagged dependent variable is in the interval of 0 and 1 , evidence of catch-up can be established, implying that countries with low levels of inclusive human development are catching-up their counterparts with higher levels.

Four main control indicators relating to information diffusion and KE are employed. In accordance with recent African KE (Tchamyou, 2015) and mobile phone (Asongu, 2015c) literatures, the mobile telephony variable is proxied with the mobile phone penetration rate (per 100 people). Three of the four pillars of the World Bank's Knowledge Economy Index 
(KEI) are employed, namely: innovation, information and communication technology (ICT) and education. First, because of issues in degrees of freedom in patent and trademark applications, the number of Scientific and Technical Journal Articles (STJA) published annually is used to proxy for innovation (Tchamyou, 2015). Second, consistent with the motivation in the introduction on the potential for ICT penetration on the continent (see Penard et al., 2012), internet penetration is used as the complementary ICT indicator. Third, education is measured with the 'pupil-teacher ratio' in primary education because compared to other educational levels, it has comparatively higher development externalities in terms of social returns when countries are still developing (see Stamatakis, 2002; Asiedu, 2014).

Four other control variables are used to account for omission variable bias, namely: GDP per capita, foreign direct investment (FDI), remittances and private domestic credit. We expect a positive nexus between the other control variables and inclusive development (Mlachila et al., 2014; Seneviratne \& Sun, 2013; Anand et al., 2012; Mishra et al., 2011; Asongu et al., 2016). According to Ssozi and Asongu (2016), remittances are expected to improve inclusive human development because they are used for consumption purposes for the most part. FDI, GDP per capita and credit facilities are determinants of growth according to Mlachila et al. (2014).

Definitions and sources of variables are disclosed in Appendix 1. The summary statistics and correlation matrix are provided respectively in Appendix 2 and Appendix 3. Two points are 'noteworthy' from the summary statistics: (i) variables' averages are comparable and (ii) corresponding variations provide us with some confidence that reasonable estimated relationships would be derived from a regression model. The objective of the correlation matrix is to provide some feeling on expected signs and errors arising from multicollinearity.

\subsection{Methodology}

\subsubsection{Specification}

The study employs the Generalised Method of Moments (GMM) with forward orthogonal deviations. There is generally a threefold interest for adopting the GMM estimation strategy. In essence, it: (i) does not eliminate cross-country variations; (ii) controls for potential endogeniety in all regressions and (iii) mitigates potential small sample biases from the difference estimator (Asongu, 2013b). It is therefore for this third interest that according to Bond et al. (2001, pp. 3-4), the system GMM estimator (Arellano \& Bover, 
1995; Blundell \& Bond, 1998) is preferred to the difference estimation proposed by Arellano and Bond (1991). We adopt an extension of Arellano and Bover (1995) cited by Roodman (2009ab) which has been shown to limit over-identification or proliferation of instruments (Love \& Zicchino, 2006; Baltagi, 2008). The GMM is preferred to other instrumental variable (IV) estimation techniques because it introduces the lagged dependent variable into the specification. Hence, it is a dynamic estimation process. Whereas other IV estimation models may also introduce the lagged dependent variable as an explanatory variable, to the best of our knowledge, only the GMM is tailored to correct for the correlation between the lagged dependent variable and error terms. In the standard GMM approach, in order to eliminate the underlying correlation, lagged levels of the regressors are used as instruments in the difference equation and lagged differences of the regressors are used as instruments in the level equation. This enables the exploitation of all orthogonal conditions between the lagged dependent variable and the error term.

The corresponding specification is a two-step GMM with forward orthogonal deviations instead of differencing. We prefer the two-step to the one-step procedure because the latter is homoscedasticity-consistent while the former controls for heteroscedasticity.

The following equations in levels (1) and first difference (2) summarize the standard system GMM estimation procedure.

$$
\begin{aligned}
& I H D_{i, t}=\sigma_{0}+\sigma_{1} I H D_{i, t-\tau}+\sigma_{2} M_{i, t}+\sigma_{3} D_{i, t}+\sigma_{4} M D_{i, t}+\sum_{h=1}^{4} \delta_{h} W_{h, i, t-\tau}+\eta_{i}+\xi_{t}+\varepsilon_{i, t} \\
& I H D_{i, t}-I H D_{i, t-\tau}= \sigma_{0}+\sigma_{1}\left(I H D_{i, t-\tau}-I H D_{i, t-2 \tau}\right)+\sigma_{2}\left(M_{i, t}-M_{i, t-\tau}\right)+\sigma_{3}\left(D_{i, t}-D_{i, t-\tau}\right)+\sigma_{3}\left(M D_{i, t}-M D_{i, t-\tau}\right) \\
&+\sum_{h=1}^{4} \delta_{h}\left(W_{h, i, t-\tau}-W_{h, i, t-2 \tau}\right)+\left(\xi_{t}-\xi_{t-\tau}\right)+\varepsilon_{i, t-\tau}
\end{aligned}
$$

Where: $I H D_{i, t}$ is inclusive human development for country $i$ at period $t ;{ }^{\sigma_{0}}$ is a constant; $M$, mobile phone penetration; $D$, diffusion of knowledge (education, ICT and innovation) ; $M D$, interaction between mobile phone penetration (M) and diffusion of knowledge (D); $W$ is the vector of control variables (GDP per capita growth, Private domestic credit, Remittances and Foreign direct investment); $\tau$ represents tau, $\xi_{t}$ is the time-specific constant, $\eta_{i}$ is the country-specific effect and $\varepsilon_{i, t}$ the error term.

\subsubsection{Identification and exclusion restriction}


Following Asongu and De Moor (2016) and Dewan and Ramaprasad (2014), we treat all independent variables as suspected endogenous or predetermined variables. Therefore, the gmmstyle is employed for them. Only years are treated as exogenous and the method for treating the ivstyle (years) is "IV (years, eq (diff))" because it is not likely that the years will become endogenous in first-difference (see Roodman, 2009b). The concern of simultaneity is addressed using lagged regressors as instruments for the forward-differenced variables. In essence, in order to eliminate fixed effects that could potentially influence the assessed connections, Helmet transformations are performed for the regressors following Arellano and Bover (1995) and Love and Zicchino (2006). These transformations embody forward meandifferencing of the indicators: the mean of all future observations is subtracted from the variables, instead of subtracting the previous observations from the contemporaneous one. The transformations enable parallel or orthogonal conditions between forward-differenced and lagged values. Irrespective of the number of lags, the underlying transformations are computable for all observations with the exception of the last for each country, in order to minimise data loss. "And because lagged observations do not enter the formula, they are valid as instruments" (see Roodman, 2009b, p. 104; Asongu \& De Moor, 2016).

On the exclusion restrictions, we argue that instruments or years which are treated as strictly exogenous affect the dependent variable exclusively through the endogenous explaining variables. The statistical validity of this exclusion restriction is investigated with the Difference in Hansen Test (DHT) for instrument exogeneity. Accordingly, the alternative hypothesis of the test should be rejected for the instruments to explain the dependent variable exclusively through the endogenous explaining indicators. Hence, the DHT procedure is used to examine whether years exhibit strict exogeneity by explaining inclusive human development exclusively through the proposed channels (or endogenous explaining variables). Therefore, reported findings should confirm the validity of the exclusion restriction if the null hypotheses of DHT corresponding to IV (year, eq(diff)) are not rejected.

\section{Empirical results}

\subsection{Presentation of results}

Consistent with Asongu and De Moor (2016), we use four information criteria in order to examine the validity of estimations. First, the second-order Arellano and Bond test for autocorrelation in difference $(\mathrm{AR}(2))$ should not be rejected. The null hypothesis corresponds to the absence of autocorrelation in the residuals. Second, the Hansen and Sargan over- 
identification restrictions (OIR) tests should also not be insignificant because their null hypotheses argue for the validity of instruments, or the absence of correlation between the instruments and error terms. It is important to note that the Sargan OIR is not robust, but not weakened by instruments while the Hansen OIR is robust but weakened by instruments. Hence, we complement the underlying OIR tests with the Difference in Hansen Test (DHT) for exogeneity of instruments. Fourth, we also provide a Fisher test for the joint validity of estimated coefficients.

Table 1: Inclusive development and mobile phones (GMM)

\begin{tabular}{|c|c|c|c|c|c|c|c|c|c|}
\hline \multirow[b]{3}{*}{ Initial IHDI } & \multicolumn{9}{|c|}{ Dependent Variable: Inequality Adjusted Human Development (IHDI) } \\
\hline & \multicolumn{3}{|c|}{ Education (Quality of education) } & \multicolumn{3}{|c|}{ Innovation (STJA) } & \multicolumn{3}{|c|}{ Internet } \\
\hline & $\begin{array}{l}0.997 * * * \\
(0.000)\end{array}$ & $\begin{array}{l}0.995 * * * \\
(0.000)\end{array}$ & $\begin{array}{l}0.996 * * * \\
(0.000)\end{array}$ & $\begin{array}{l}\text { 0.999**** } \\
(0.000)\end{array}$ & $\begin{array}{l}0.999 * * * * \\
(0.000)\end{array}$ & $\begin{array}{l}0.999 * * * * \\
(0.000)\end{array}$ & $\begin{array}{l}0.999 * * * * \\
(0.000)\end{array}$ & $\begin{array}{l}1.001 * * * * \\
(0.000)\end{array}$ & $\begin{array}{l}\text { 1.001**** } \\
(\mathbf{0 . 0 0 0 )}\end{array}$ \\
\hline Constant & $\begin{array}{l}-0.003 \\
(0.620)\end{array}$ & $\begin{array}{l}-\mathbf{0 . 0 4 2} * * \\
(\mathbf{0 . 0 3 3})\end{array}$ & $\begin{array}{l}-0.036 \\
(0.182)\end{array}$ & $\begin{array}{l}0.003 \\
(0.232)\end{array}$ & $\begin{array}{l}-0.003 \\
(0.514)\end{array}$ & $\begin{array}{l}0.009 \\
(0.421)\end{array}$ & $\begin{array}{l}0.006 * * * \\
(0.002)\end{array}$ & $\begin{array}{l}-0.002 \\
(0.622)\end{array}$ & $\begin{array}{l}-0.00003 \\
(0.995)\end{array}$ \\
\hline Mobile phones (Mob) & $\begin{array}{l}0.0001 \\
(0.490)\end{array}$ & $\begin{array}{l}-0.0001 \\
(0.424)\end{array}$ & $\begin{array}{l}-0.0004 \\
(0.191)\end{array}$ & $\begin{array}{l}0.00003 \\
(0.758)\end{array}$ & $\begin{array}{l}-0.00009 \\
(0.429)\end{array}$ & $\begin{array}{l}-0.00004 \\
(0.796)\end{array}$ & $\begin{array}{l}0.00002 \\
(0.763)\end{array}$ & $\begin{array}{l}0.0003 * * * \\
(0.000)\end{array}$ & $\begin{array}{l}0.0003 * * * \\
(0.001)\end{array}$ \\
\hline Education & $\begin{array}{l}0.0002 * \\
(0.055)\end{array}$ & $\begin{array}{l}0.0007 * * * \\
(0.001)\end{array}$ & $\begin{array}{l}0.0008 * * * \\
(0.003)\end{array}$ & & & --- & --- & --- & --- \\
\hline Innovation (STJA) & --- & --- & --- & $\begin{array}{l}0.00003 \\
(0.705)\end{array}$ & $\begin{array}{l}-0.000 \\
(0.951)\end{array}$ & $\begin{array}{l}0.00004 \\
(0.716)\end{array}$ & --- & --- & --- \\
\hline Internet & --- & --- & --- & --- & --- & --- & $\begin{array}{l}0.0004 \\
(0.506)\end{array}$ & $\begin{array}{l}0.001 * * * \\
(0.003)\end{array}$ & $\begin{array}{l}0.001 * * \\
(0.026)\end{array}$ \\
\hline Education.Mob & $\begin{array}{l}-0.000 \\
(0.660)\end{array}$ & $\begin{array}{l}0.000 \\
(0.230)\end{array}$ & $\begin{array}{l}0.000 \\
(0.247)\end{array}$ & --- & --- & --- & --- & --- & --- \\
\hline STJA.Mob & --- & --- & --- & $\begin{array}{l}-0.000 \\
(0.682)\end{array}$ & $\begin{array}{l}-0.000 \\
(0.974)\end{array}$ & $\begin{array}{l}-0.000 \\
(0.797)\end{array}$ & --- & --- & --- \\
\hline Internet.Mob & --- & --- & --- & --- & --- & --- & $\begin{array}{l}-0.000 \\
(0.397)\end{array}$ & $\begin{array}{l}-\mathbf{- 0 . 0 0 0 0 1} \\
* * * \\
(\mathbf{0 . 0 0 5 )}\end{array}$ & $\begin{array}{l}- \\
0.00001 * * \\
(0.021)\end{array}$ \\
\hline GDP per capita & --- & $\begin{array}{l}0.0006 * * * \\
(0.002)\end{array}$ & $\begin{array}{l}0.0007 * * \\
(0.040)\end{array}$ & --- & $\begin{array}{l}0.0005 * * * \\
(0.004)\end{array}$ & $\begin{array}{l}0.0002 \\
(0.353)\end{array}$ & --- & $\begin{array}{l}0.0006 * * * \\
(0.000)\end{array}$ & $\begin{array}{l}0.0003 * * * \\
(0.005)\end{array}$ \\
\hline Private Credit & -- & $\begin{array}{l}0.0006 \\
(0.297)\end{array}$ & $\begin{array}{l}0.0006 \\
(0.356)\end{array}$ & --- & $\begin{array}{l}0.0004 \\
(0.234)\end{array}$ & $\begin{array}{l}-0.0001 \\
(0.815)\end{array}$ & --- & $\begin{array}{l}-\mathbf{0 . 0 0 1} * * * * \\
(0.000)\end{array}$ & $\begin{array}{l}-0.001 * * * * \\
(0.000)\end{array}$ \\
\hline Remittances & --- & --- & $\begin{array}{l}-0.0002 \\
(0.160)\end{array}$ & --- & --- & $\begin{array}{l}-0.0002 \\
(0.362)\end{array}$ & --- & --- & $\begin{array}{l}- \\
0.0005 * * * \\
(0.000)\end{array}$ \\
\hline FDI & --- & --- & $\begin{array}{l}\text { 0.0006*** } \\
(0.020)\end{array}$ & --- & --- & $\begin{array}{l}0.0002 \\
(0.482)\end{array}$ & --- & --- & $\begin{array}{l}0.0007 * * * * \\
(\mathbf{0 . 0 0 0 )}\end{array}$ \\
\hline $\operatorname{AR}(1)$ & $(0.528)$ & (0.719) & $(0.698)$ & $(0.718)$ & $(0.949)$ & $(0.965)$ & $(0.202)$ & $(0.001)$ & $(0.002)$ \\
\hline $\mathrm{AR}(2)$ & $(0.924)$ & $(0.367)$ & $(0.902)$ & $(0.283)$ & $(0.420)$ & $(0.850)$ & $(0.324)$ & $(0.396)$ & $(0.608)$ \\
\hline Sargan OIR & $(0.000)$ & $(0.000)$ & $(0.000)$ & $(0.000)$ & $(0.000)$ & $(0.000)$ & $(0.000)$ & $(0.000)$ & $(0.000)$ \\
\hline Hansen OIR & $(0.769)$ & $(0.930)$ & $(0.995)$ & $(0.942)$ & $(0.994)$ & (1.000) & $(0.648)$ & (0.171) & $(0.707)$ \\
\hline $\begin{array}{l}\text { DHT for instruments } \\
\text { (a)Instruments in levels }\end{array}$ & & & & & & & & & \\
\hline H excluding group & $(0.406)$ & $(0.518)$ & $(0.662)$ & $(0.871)$ & $(0.886)$ & (0.988) & $(0.467)$ & $(0.322)$ & $(0.524)$ \\
\hline $\begin{array}{l}\text { Dif(null, H=exogenous) } \\
\text { (b) IV (years, eq(diff)) }\end{array}$ & $(0.822)$ & $(0.958)$ & $(0.998)$ & $(0.845)$ & $(0.981)$ & $(1.000)$ & $(0.628)$ & (0.167) & $(0.691)$ \\
\hline $\mathrm{H}$ excluding group & na & $(0.886)$ & $(0.671)$ & $(0.431)$ & $(0.935)$ & $(0.996)$ & na & $(0.567)$ & $(0.497)$ \\
\hline Dif(null, $\mathrm{H}=$ exogenous) & $(0.769)$ & $(0.795)$ & $(1.000)$ & $(0.965)$ & $(0.970)$ & (1.000) & $(0.648)$ & (0.089) & $(0.762)$ \\
\hline Fisher & $3.14 \mathrm{e}+08$ & $1.73 e+08$ & $2.81 e+06$ & $3.92 e+08$ & $3.46 \mathrm{e}+08$ & $5.67 e+07$ & $1.18 \mathrm{e}+08$ & $9.40 \mathrm{e}+08$ & $2.88 \mathrm{e}+09$ \\
\hline
\end{tabular}




\begin{tabular}{|c|c|c|c|c|c|c|c|c|c|}
\hline & $* * *$ & $* * *$ & $* * *$ & $* * *$ & $* * *$ & $* * *$ & $* * *$ & $* * *$ & $* * *$ \\
\hline Instruments & 25 & 33 & 41 & 23 & 31 & 39 & 25 & 33 & 41 \\
\hline Countries & 41 & 40 & 35 & 34 & 34 & 31 & 43 & 42 & 37 \\
\hline Observations & 296 & 280 & 242 & 294 & 281 & 232 & 365 & 341 & 282 \\
\hline
\end{tabular}

*, **, ***: significance levels of 10\%, 5\% and 1\% respectively. STJA: Scientific and Technical Journal Articles. GDP: Gross Domestic Product. FDI: Foreign Direct Investment. DHT: Difference in Hansen Test for Exogeneity of Instruments' Subsets. Dif: Difference. OIR: Over-identifying Restrictions Test. The significance of bold values is twofold. 1) The significance of estimated coefficients, Hau sman test and the Fisher statistics. 2) The failure to reject the null hypotheses of: a) no autocorrelation in the $A R(1)$ and $A R(2)$ tests and; b) the validity of the instruments in the Sargan OIR test. na: thresholds and/or net effects cannot be computed because of insignificant marginal effects.

Five key findings are established from Table 1.

First, catch-up in inclusive development is apparent in education- and innovationoriented regressions for the most part because the absolute values of the lagged endogenous variables are in accordance with the information criterion or between 0 and 1. For brevity and lack of space, the interested reader can refer to Fung (2009, p. 58) and Asongu (2013b, p. 49) for more insights into the convergence criterion. It is important to note that in the standard dynamic GMM approach the estimated coefficient can be reported and one subtracted from it to obtain $\beta(\beta=\mathrm{a}-1)$. Within this framework, the information criterion for catch-up is when $\beta<0$. The lagged estimated variable could also be reported and the alternative criterion (' $0<$ lagged value $<1$ ') used to assess catch-up (see Prochniak \& Witkowski, 2012a, p. 20; Prochniak \& Witkowski, 2012b, p. 23). Hence, evidence of convergence can be established when the absolute value of the lagged endogenous variable is between 0 and 1 .

Second, the effect of mobile phones is significant in the third-set of specifications (or last-two columns).

Third, the effects from education and internet penetration are positive.

Fourth, the marginal effects are negative from internet penetration. Overall the information diffusion and KE variables are significant with expected signs.

Fifth, most of the other significant control variables have the expected signs.

\subsection{Further discussion of results and policy implications}

Before discussing the implications for catch-up, it is necessary to clarify the concepts of diminishing dispersions. Asongu, (2013b) and Narayan et al., (2011) explained that absolute catch-up is fundamentally based on common initiatives, policies and factors which include, inter alia, economic unions and common monetary areas. The context of this inquiry extends well beyond common monetary/economic zones to shared policy initiatives on inclusive human development across countries. Hence, this form of catch-up indicates that 
countries share common fundamental goals such as the SDGs. The absence of this form of catch-up may be the result of differences in initial levels of inclusive human development across countries. Conversely, conditional catch-up is of the type where-by a nation's longterm equilibrium outcome depends on certain structural factors that are fundamental to the response variable. Therefore, such a form of catch-up is likely to occur when there are crosscountry disparities in factors that determine the underlying dependent variable (inclusive human development). It follows that if sampled nations differ in elements of the conditioning information set, catch-up in inclusive human development may be apparent.

In the light of the above, catch-up in inclusive human development is contingent on the mobile phone and knowledge diffusion variables. In other words, a knowledge economy is necessary for countries in the sub-region with low inclusive development to catch-up their counterparts with higher levels of inclusive development. Consistent with the theoretical underpinnings, the reduction in cross-country differences in inclusive human development is fundamentally due to 'knowledge economy-driven policies. Moreover, such catch-up implies that common KE policies are feasible. In essence, policy harmonization efforts may be crucial to tackling common post-2015 Sustainable Development Goals (SDGs) challenges, given that $\mathrm{KE}$ has been documented to be conducive for inclusive and sustainable development (Lustig, 2011). In what follows, we provide some suggestions on KE policies that can be commonly adopted in the sub-region for the post-2015 development agenda. The suggestions are how to leverage common knowledge economy initiatives for inclusive development.

As with the South Korean experience (Tchamyou, 2015), soundly-integrated policy measures embodying an active information policy, an industrial policy and regulatory policy may improve the complementary role of ICT for more pro-poor development. With regard to innovation, it is a fact that the current technological capacities in African countries are more imitative and adaptive (Asongu, 2014c, p. 579). Therefore as argued by Bezmen and Depken (2004), innovation is more likely in the sub-region through copying of technology-intensive commodities because composite nations are at their initial stages of industrialization (also see Kim, 1997; Kim et al., 2012; Km \& Kim, 2014). Hence, innovation policies tailored towards less tight property rights are essential for reversed engineering, informal technology transfer and know-how in commodities that are technology-intensive because countries in SSA are at an early industrialization phase. This policy recommendation is in accordance with a recent strand on African KE literature which has established that less tight intellectual property rights (IPRs) mitigate poverty (Asongu, 2014d) and boost STJA (Asongu, 2014c), which is 
the proxy for innovation used in this inquiry. Therefore, policies encouraging innovation would go a long way to reducing poverty and increasing standards of living in SSA in the post-2015 development era.

\section{Conclusion and future research directions}

The success of inclusive development strategies in the post-2015 sustainable development agenda substantially depends on the adoption of common inclusive development policies among nations. This is essentially because common development goals also require common development strategies. Sub-Saharan Africa (SSA) failed to achieve the Millennium Development Goal (MDG) initiative to halve extreme poverty by 2015 because according to the World Bank more than 45 percent of countries in the sub-region were still living below the extreme poverty line by the end of 2015.

Building on the relevance of a knowledge economy in the post-2015 development agenda, this study models the feasibility of shared policies for inclusive human development in the sub-region. For this purpose, we investigate the complementary role of knowledge diffusion in the inclusive benefits of mobile phone penetration in SSA for the period 20002012 by employing the Generalised Method of Moments. Knowledge diffusion variables include educational quality, innovation and internet penetration. The main finding is that inclusive human development is persistently conditional on mobile phones in knowledge diffusion. Moreover, countries with low levels of inclusive human development are catchingup their counterparts with higher development. Policy implications are discussed with particular emphasis on how to leverage common knowledge economy initiatives for inclusive development.

Future inquiries can extend this study by employing other indicators of inclusive and sustainable development. Moreover, decomposition of the inequality-adjusted human development index in order to assess how its different components influence the convergence process is worthwhile. 


\section{Appendices}

\section{Appendix 1: Definitions and sources of variables}

\begin{tabular}{llll}
\hline Variables & Signs & Definitions & Sources \\
\hline $\begin{array}{l}\text { Inclusive } \\
\text { development }\end{array}$ & IHDI & Inequality Adjusted Human Development Index & UNDP \\
Mobile Phone & Mobile & Mobile phone subscriptions (per 100 people) & WDI \\
Educational Quality & Educ & Pupil teacher ratio in Primary Education & WDI \\
Innovation & STJA & Scientific and Technical Journal Articles & WDI \\
Internet & Internet & Internet penetration (per 100 people) & WDI \\
GDP per capita & GDPpcg & GDP per Capita growth rate & WDI \\
Private Credit & Credit & Private credit by deposit banks and other & WDI \\
Remittances & Remit & Remittances inflows (\% of GDP) & WDI \\
Foreign investment & FDI & Foreign Direct Investment net inflows (\% of & \\
\end{tabular}

UNDP: United Nations Development Program. WDI: World Development Indicators. GDP: Gross Domestic Product.

\section{Appendix 2: Summary statistics}

Inequality Adj. Human Development

Mobile Phone Penetration

Educational Quality

Innovation (STJA)

Internet Penetration

GDP per Capita growth

Private Domestic Credit

Remittances

Net Foreign Direct Investment Inflows

\begin{tabular}{lllll} 
Mean & SD & Min & Max & Obs \\
\hline 0.721 & 3.505 & 0.129 & 0.768 & 485 \\
23.379 & 28.004 & 0.000 & 147.202 & 572 \\
43.601 & 14.529 & 12.466 & 100.236 & 444 \\
91.231 & 360.522 & 0.000 & 2915.5 & 480 \\
4.152 & 6.450 & 0.005 & 43.605 & 566 \\
2.198 & 5.987 & -49.761 & 58.363 & 608 \\
18.551 & 22.472 & 0.550 & 149.78 & 507 \\
3.977 & 8.031 & 0.000 & 64.100 & 434 \\
5.332 & 8.737 & -6.043 & 91.007 & 603
\end{tabular}

SD: Standard deviation. Min: Minimum. Max: Maximum. Obs: Observations. Adj: Adjusted.

\section{Appendix 3: Correlation Matrix (Uniform sample size : 233)}

\begin{tabular}{|c|c|c|c|c|c|c|c|c|c|}
\hline \multicolumn{3}{|c|}{ Diffusion of Knowledge } & \multicolumn{4}{|c|}{ Control Varaibles } & \multirow{2}{*}{$\begin{array}{c}\text { Ind. Vble } \\
\text { Mobile }\end{array}$} & \multirow{2}{*}{$\begin{array}{l}\text { Dep. Vble } \\
\text { IHDI }\end{array}$} & \multirow[b]{3}{*}{ Fdu } \\
\hline Edu & STJA & Internet & GDPpcg & Credit & Remit & FDI & & & \\
\hline \multirow[t]{9}{*}{1.000} & -0.127 & -0.484 & 0.029 & -0.369 & -0.073 & -0.118 & -0.461 & -0.096 & \\
\hline & 1.000 & -0.124 & 0.036 & 0.779 & -0.083 & -0.062 & 0.221 & 0.701 & STJA \\
\hline & & 1.000 & 0.043 & 0.479 & -0.039 & 0.060 & 0.746 & 0.088 & Internet \\
\hline & & & 1.000 & 0.014 & 0.035 & 0.131 & -0.003 & -0.023 & GDPpcg \\
\hline & & & & 1.000 & -0.096 & -0.117 & 0.471 & 0.599 & Credit \\
\hline & & & & & 1.000 & 0.078 & -0.058 & -0.050 & Remit \\
\hline & & & & & & 1.000 & 0.114 & -0.026 & FDI \\
\hline & & & & & & & 1.000 & 0.049 & Mobile \\
\hline & & & & & & & & 1.000 & IHDI \\
\hline
\end{tabular}

Edu : Educational quality. STJA: Scientific \& Technical Journal Articles. Internet: Internet Penetration. GDPpcg : GDP per capita growth rate. Credit: Private domestic credit. Remit: Remittances. FDI: Foreign Direct Investment. Mobile: Mobile Phone Penetration. IHDI: Inequality Adjusted Human Development Index. Ind. Vble: Independent Variable. Dep. Vble: Dependent Variable. 


\section{References}

Aker, J. C., \& Fafchamps, M., (2010). "How Does Mobile Phone Coverage Affect Farm-Gate Prices? Evidence from West Africa", Department of Economics and the Fletcher School, Tufts University.

Al Surikhi, H. F., (2012). "Knowledge and Financial Management in Households: An Examination of Married Women's Perspectives in Chadbourn, North Carolina", Capstone Collection, Paper No. 2489.

Anand, R., Mishra, S., \& Spatafora, N., (2012), "Structural Transformation and the Sophistication of Production," IMF Working Paper No. 12/59, Washington.

Anyanwu, J. C., (2012). "Developing Knowledge for the Economic Advancement of Africa", International Journal of Academic Research in Economics and Management Sciences, 1(2), pp. 73-111.

Arellano, M., \& Bond, S., (1991), "Some tests of specification for panel data: Monte Carlo evidence and an application to employment equations" The Review of Economic Studies, 58(2), pp. 277-297.

Arellano, M., \& Bover, O., (1995), "Another look at the instrumental variable estimation of errorcomponents models", Journal of Econometrics, 68(1), pp. 29-52.

Asiedu, E., (2014). "Does Foreign Aid in Education Promote Economic Growth? Evidence From Sub-Saharan Africa”, Journal of African Development, 16(1), pp. 37-59.

Asongu, S. A., (2013a). "How has mobile phone penetration stimulated financial development in Africa", Journal of African Business, 14(1), pp. 7-18.

Asongu, S. A., (2013b). "Harmonizing IPRs on Software Piracy: Empirics of Trajectories in Africa”, Journal of Business Ethics, 118(1), pp. 45-60.

Asongu, S. A., (2014a). "Mobile banking and mobile phone penetration: which is more propoor in Africa?", African Governance and Development Institute Working Paper No. 13/033, Yaoundé. Revised and Resubmitted: African Finance Journal.

Asongu, S. A., (2014b). "African development: beyond income convergence”, South African Journal of Economics, 83(3), pp. 334-353.

Asongu, S. A., (2014c). "Software Piracy and Scientific Publications: Knowledge Economy Evidence from Africa”, African Development Review, 26(4), pp. 572-583.

Asongu, S. A., (2014d). "Software piracy, inequality and the poor: evidence from Africa", Journal of Economic Studies, 41(4), pp. 526-553.

Asongu, S. A., (2015a). "Knowledge Economy Gaps, Policy Syndromes and Catch-Up Strategies: Fresh South Korean Lessons to Africa", Journal of the Knowledge Economy, http://link.springer.com/article/10.1007/s13132-015-0321-0 
Asongu, S. A. (2015b). "The Comparative Economics of Knowledge Economy in Africa: Policy Benchmarks, Syndromes and Implications", Journal of the Knowledge Economy, http://link.springer.com/article/10.1007/s13132-015-0273-4

Asongu, S. A., (2015c). "Conditional Determinants of Mobile Phones Penetration and Mobile Banking in Sub-Saharan Africa", Journal of the Knowledge Economy.

http://link.springer.com/article/10.1007\%2Fs13132-015-0322-z

Asongu, S. A., (2015d). "The impact of mobile phone penetration on African inequality", International Journal of Social Economics, 42(8), pp. 706 - 716

Asongu, S. A., \& De Moor, L., (2015). "Recent advances in finance for inclusive development: a survey", African Governance and Development Institute Working Paper No. 15/005, Yaoundé.

Asongu, S. A., \& De Moor, L., (2016). "Financial globalisation dynamic thresholds for financial development: evidence from Africa", European Journal of Development Research: DOI:10.1057/ejdr.2016.10.

Asongu, S. A., Efobi, U., \& Beecroft, I., (2015). "Inclusive Human Development in Pre-Crisis Times of Globalisation-Driven Debts", African Development Review: 27(4), pp. 428-442.

Asongu, S. A., Boateng, A., \& Akamavi, R., (2016). "Mobile Phone Innovation and Inclusive Human Development: Evidence from Sub-Saharan Africa", African Governance and Development Institute Working Paper.

Asongu, S. A., \& Nwachukwu, J. C., (2016). "Revolution empirics: predicting the Arab Spring”, Empirical Economics, Forthcoming. http://link.springer.com/article/10.1007/s00181-015-1013-0

Baltagi, B. H., (2008). "Forecasting with panel data", Journal of Forecasting, 27(2), pp. 153173.

Barro, R., (1991). "Economic Growth in a Cross Section of Countries". Quarterly Journal of Economics, 196 (2/May), pp. 407-443.

Barro, R. J., \& Sala-i-Martin, X., (1992). “Convergence”, Journal of Political Economy, 100(2), pp. 223-251.

Barro, R. J., \& Sala-i-Martin, X., (1995). Economic Growth. The MIT Press, Cambridge, MA.

Bauer, S., De Niet, J., Timman, R., \& Kordy, H., (2010). "Enhancement of care through selfmonitoring and tailored feedback via text messaging and their use in the treatment of childhood overweight", Patient Education and Counseling, 79 (2010), pp. 315-319.

Beck, T., Demirgüç-Kunt, A., \& Levine, R., (2003), "Law and finance: why does legal origin matter?", Journal of Comparative Economics, 31(4), pp. 653-675. 
Baumol, W. J., (1986). "Productivity, growth, convergence and welfare: what the long run data show", American Economic Review, 76(5), pp. 1072-1085.

Blundell, R., \& Bond, S., (1998). "Initial conditions and moment restrictions in dynamic panel data models" Journal of Econometrics, 87(1), pp. 115-143.

Bond, S., Hoeffler, A., \& Tample, J. (2001) “GMM Estimation of Empirical Growth Models", University of Oxford.

Bruno, G., De Bonis, R., \& Silvestrini, A., (2012). "Do financial systems converge? New evidence from financial assets in OECD countries". Journal of Comparative Economics; 40(1), pp. 141-155.

Chan, A., \& Jia, T., (2011). "The Role of Mobile Banking in Facilitating Rural Finance: Reducing Inequality in Financial Services between Urban and Rural Areas", Accenture Banking Services, http://www.accenture.com/SiteCollectionDocuments/PDF/PoV-MobileBanking-051611-EN.pdf (Accessed: 17/03/2015).

Da Costa, T. M. Salomão, P. L., Martha, A. S., Pisa, I. T., \& Sigulem, D., (2010). "The impact of short message service text messages sent as appointment reminders to patients' cell phones at outpatient clinics in São Paulo, Brazil", International Journal of Medical Informatics, 79 (2010), pp. 65-70.

Dewan, S., \& Ramaprasad, J., (2014). "Social media, traditional media and music sales", MIS Quarterly, 38(1), pp. 101-128.

E-agriculture (2012). "Using ICT to enable Agricultural Innovation Systems for Smallholders", e-source book, ICT In Agriculture, Connecting Small Holders to Knowledge, Networks and Institutions, (Forum 4, September 2012).

http://www.fao.org/docrep/018/ar130e/ar130e.pdf (Accessed: 18/03/2015).

Fosu, A. K., (2015a). "Growth, Inequality and Poverty in Sub-Saharan Africa: Recent Progress in a Global Context”, Oxford Development Studies, 43(1), pp. 44-59.

Fosu, A., (2015b). Growth and Institutions in African Development, First edited by Augustin K. Fosu, , Routledge Studies in Development Economics: New York

Fosu, A., (2015c). Growth and institutions in African Development, in Growth and Institutions in African Development, First edited by Augustin K. Fosu, 2015, Chapter 1, pp. 1-17, Routledge Studies in Development Economics: New York.

Fung, M. K., (2009). "Financial development and economic growth: Convergence or divergence?", Journal of International Money and Finance, 28(1), pp. 56-67.

Hoffman, J. A., Cunningham, J. R., Suleh, A. J., Sundsmo, A., Dekker, D., Vago, F., \& Munly, K., (2010). "Mobile Direct Observation Treatment for Tuberculosis Patients A Technical Feasibility Pilot Using Mobile Phones in Nairobi, Kenya", American Journal of Preventive Medicine, 39(1), pp. 78-80. 
Jonathan, D., \& Camilo, T. (2008). "Mobile banking and economic development: Linking adoption, impact and use". Asian Journal of Communication, 18(4), 318-322.

Kim, E. M., (1997). Big Business, Strong State: Collusion and Conflict in South Korean Development, 1960-1990. State University of New York Press: New York.

Kim, E. M., and Kim, P. H., (2014). The South Korean Development Experience: Beyond Aid. Critical Studies of the Asia Pacific, Palgrave Macmillan.

Kim, Y., Lee, K., Park, W. G., \& Choo, K., (2012). "Appropriate intellectual property protection and economic growth in countries at different levels of development", Research Policy, 41(2), pp. 358-375.

Kirui, O. K., Okello, J. J., Nyikal, R. A., \& Njiraini, G. W., (2013). "Impact of Mobile PhoneBased Money Transfer Services in Agriculture: Evidence from Kenya", Quaterly Journal of International Agriculture, 52(2), pp. 141-162.

Kliner, M., Knight, A., Mamvura, C., Wright, J., \& Walley, J., (2013). "Using no-cost mobile phone reminders to improve attendance for HIV test results: a pilot study in rural Swaziland", Infectious Diseases of poverty, 2(12), pp. 1-7.

Kuada, J., (2015). Private Enterprise-Led Economic Development in Sub-Saharan Africa The Human Side of Growth First edition by Kuada, J, Palgrave Macmillan: New York.

Love, I., \& Zicchino, L., (2006). "Financial Development and Dynamic Investment Behaviour: Evidence from Panel VAR" .The Quarterly Review of Economics and Finance, 46(2), pp. 190-210.

Lustig, N., (2011). “The Knowledge Bank and Poverty Reduction”, Working Papers No. 209, ECINEQ, Society for the Study of Economic Inequality.

Mankiw, N. G., Romer, D., \& Weil, D. N., (1992). "A contribution to the empirics of economic growth”, Quarterly Journal of Economics, 107 (May, 1992), pp. 407-437.

Maurer, B. (2008, May). Retail electronic payments systems for value transfers in the developing world. Department of Anthropology, University of California.

Mayer-Foulkes, D., (2010). "Divergences and Convergences in Human Development". UNDP Human Development Research Paper 2010/20.

McDonald, J., (2009), "Using Least Squares and Tobit in Second Stage DEA Efficiency Analyses”, European Journal of Operational Research, 197(2), pp. 792-798.

Mishra, V., \& Bisht, S. S., (2013). "Mobile banking in a developing economy: A customercentric model for policy formulation", Telecommunications Policy, 37(6-7), pp. 503-514.

Mishra, S., Gable, S. L., \& Anand, R., (2011), "Service Export Sophsitication and Economic Growth," World Bank Policy Working Paper No. 5606, Washington. 
Mlachila, M., Tapsoba, R., \& Tapsoba, S. J. A., (2014). “A Quality of Growth Index for Developing Countries: A Proposal”, IMF Working Paper No. 14/172, Washington.

Mpogole, H., Usanga, H., \& Tedre, M., (2008). "Mobile phones and poverty alleviation: a survey study in rural Tanzania", Proceedings of M4D 2008, Karlstad University, Sweden, pp. $62-72$.

Muto, M., \& Yamano, T., (2009). "The Impact of Mobile Phone Coverage Expansion on Market Participation: Panel Data Evidence from Uganda", World Development, 37(12), pp. 1887-1896.

Narayan, P.K., Mishra, S., \& Narayan, S., (2011). "Do market capitalization and stocks traded converge? New global evidence". Journal of Banking and Finance, 35(10), pp.2771-2781.

Ojo, A., Janowski, T., \& Awotwi, J., (2012). "Enabling development through governance and mobile technology", Government Information Quarterly, 30 (2013), pp. S32-S45.

Oluwatobi, S., Efobi, U.R., Olurinola, O.I., Alege, P. (2015), "Innovation in Africa: Why Institutions Matter", South African Journal of Economics, 83(3), pp. 390-410.

Ondiege, P., (2013). "Fostering financial inclusion with mobile banking", African

Development Bank.

http://www.proparco.fr/webdav/site/proparco/shared/PORTAILS/Secteur_prive_developpeme nt/PDF/SPD16/SPD16_Peter_Ondiege_UK.pdf (Accessed: 03/02/2015).

Ondiege, P., (2010). "Mobile Banking in Africa: Taking the Bank to the People", Africa Economic Brief, 1(8), pp. 1-16.

Penard, T., Poussing, N., Yebe, G. Z., \& Ella, P. N., (2012). "Comparing the Determinants of Internet and Cell Phone Use in Africa: Evidence from Gabon ", Communications \& Strategies, 86, pp. 65-83.

Petrakis, P. E., \& Stamatakis, D. (2002). “Growth and educational levels: a comparative analysis”. Economics of Education Review, 21 (2), pp. 513-521.

Pritchett, L., (1997). "Divergence, Big Time”. Journal of Economic Perspectives, 11(3), pp. 3-17.

Prochniak, M., \& Witkowski, B., (2012a). "Beta convergence stability among "Old” and "New" EU countries: The Bayesian Model Averaging Perspective", Warsaw School of Economics.

Prochniak, M., \& Witkowski, B., (2012b). "Real economic convergence and the impact of monetary policy on economic growth of the EU countries: The analysis of time stability and the identification of major turning points based on the Bayesian methods", Warsaw School of Economics.

Qiang, C. Z., Kuek, S. C., Dymond, A., \& Esselaar, S., (2011). "Mobile Applications for Agricultural and Rural Development", ICT Sector Unit, World Bank http://siteresources.worldbank.org/INFORMATIONANDCOMMUNICATIONANDTECHN OLOGIES/Resources/MobileApplications_for_ARD.pdf (Accessed: 17/03/2015). 
Roodman, D., (2009a). “A Note on the Theme of Too Many Instruments", Oxford Bulletin of Economics and Statistics, 71(1), pp. 135-158.

Roodman, D., (2009b). "How to do xtabond2: An introduction to difference and system GMM in Stata", Stata Journal, 9(1), pp. 86-136.

Seneviratne, D., \& Sun, Y., (2013), "Infrastructure and Income Distribution in ASEAN-5: What are the Links?" IMF Working Paper No. 13/41, Washington.

Singh, A. B., (2012). "Mobile banking based money order for India Post: Feasible model and assessing demand potential”, Procedia - Social and Behavioral Sciences, 37, pp. 466-481.

Solow, R. M., (1956). "A contribution to the theory of economic growth", Quarterly Journal of Economics, 70(1), pp. 65-94.

Ssozi, J., \& Amlani, S., (2015) "The Effectiveness of Health Expenditure on the Proximate and Ultimate Goals of Healthcare in Sub-Saharan Africa", Economics Department, Hankamer School of Business, Baylor University.

Ssozi, J., \& Asongu, S. A., (2015). " The Effects of Remittances on Output per Worker in Sub-Saharan Africa: A Production Function Approach", South African Journal of Economics, http://onlinelibrary.wiley.com/doi/10.1111/saje.12100/abstract

Swan, T., (1956). "Economic growth and capital accumulation”. Economic Record, 32(2), pp. 334-361.

Tchamyou, V. S., (2015). "The role of knowledge economy in African business", African Governance and Development Institute Working Paper No. 15/049, Yaoundé.

Warren, M., (2007). "The digital vicious cycle: links between social disadvantage and digital exclusion in rural areas". Telecommunications Policy, 31(6-7), pp. 374-388.

West, D. M., (2013). "Improving Health Care through Mobile Medical Devices and Sensors", Centre for Technology and Innovation at Brookings, http://www.brookings.edu/ /media/research/files/papers/2013/10/22\%20mobile\%20medical \%20devices\%20west/west_mobile\%20medical\%20devices_v06 (Accessed: 19/03/2015).

World Bank (2015). "World Development Indicators", World Bank Publications http://www.gopa.de/fr/news/world-bank-release-world-development-indicators-2015 (Accessed: 25/04/2015). 